\title{
International Business English Program: Processes and Considerations for Design
}

\section{Programa de inglés en negocios internacionales: procesos y consideraciones sobre su diseño}

\author{
Angela BaILey \\ Universidad del Norte \\ (Barranquilla, Colombia) \\ Lourdes REY \\ Universidad del Norte \\ (Barranquilla, Colombia) \\ Nayibe RosADo \\ Universidad del Norte \\ (Barranquilla, Colombia)
}

\begin{abstract}
Designing courses can be a long and difficult process. In this paper the authors share a design project, which they are involved with at the Instituto de Idiomas at the Universidad del Norte in Barranquilla, Colombia for International Business majors. The authors share the difficulties of deciding the path to take in course design, especially content oriented, the considerations made during the design of the program, and the plan for further development. In the end, the authors invite all teachers to participate in course design as it is an enriching experience as well as a complicated process.
\end{abstract}

Key Words: business English; content-based instruction; course design.

\section{Resumen}

El diseño de un curso puede ser un proceso largo y dificil. En esta ponencia, las autoras comparten un proyecto de diseño para los cursos de profundización en negocios internacionales a su cargo con el Instituto de Idiomas de la Universidad del Norte en Barranquilla, Colombia. Las autoras comparten las dificultades que se presentan al decidir el camino a seguir en el diseño de un curso, especialmente aquel que se basa en contenidos; las consideraciones a tener en cuenta durante el diseño del programa y el plan a trazar para un futuro desarrollo del mismo. Finalmente, las autoras invitan a todos los docentes a participar en el diseño de cursos como una experiencia enriquecedora y un proceso complicado.

Palabras Claves: inglés de negocios; instrucción basado en contenido; diseño de cursos.

\section{INTRODUCTION}

Designing courses can be a long and difficult process. Not only the policies and practices of an institution need to be considered, but also and most importantly, all the needs, wants and expectations of the students, teachers and administrators involved in the process. Designing content courses need the added fact of professional preparation and skills. Typical approaches to content-based instruction (CBI) have specific characteristics. The characteristics and design according to Stoller (2002) are: promote the integration of language, content, and strategy 
learning; demonstrate that language is a medium for learning content and content is the resource for learning and improving language; allow that content drives the instructional decisions; develop purposeful and meaningful language use in the classroom; encourage participation; and focus on the development of discourse-level abilities (p. 109). Designing the Business English Program at the Instituto de Idiomas, Universidad del Norte, Barranquilla, Colombia has been a challenge and an experience.

In 2004, the Instituto de Idiomas was invited to assist the Business Department in creating courses with content purposes for their new program of International Business. We accepted the challenge and began planning and designing the program of Business English. Our first and most important decision was to design a student profile. So, we decided that the students of the International Business program should have a minimum entry level equivalent to our regular program level four. In the Common European Framework, level four corresponds to A2.2 which describes a speaker who is capable of sustaining a basic conversation and a reader who can understand regular texts and interpret them. This action, in turn, typically invites a more elite group of students into the program because the bilingual schools and schools which focus heavily on English acquisition turn out better language users than schools who have English classes once a week. To this day, the students are able to enter at A2.2, but we prefer B1 because of the texts we now use inside the classroom.

This paper will describe the process carried out for the design and implementation of the English Program for the International Business majors at Universidad del Norte in Barranquilla, Colombia. It will describe the different phases involved in designing this language-centered content program as well as the considerations taken throughout the process. We will also discuss our future program courses and how we are developing and plan to develop them. The final word will invite you to challenge yourselves and your own methods to course design that fits into your context.

\section{PHASE 1: CHOOSING THE WAY}

In the beginning of the program, the Instituto de Idiomas considered that the first four levels of our Business program (the whole program consists of 8 levels in total: four more language oriented and four more content) would follow the curriculum design of our current undergraduate program and be called English 1-4; the only differences being that their English program would be taught separately from the regular English program offered at the Instituto and the courses would add in Business elements throughout. This in turn would allow the students to finish their more general English courses before their third semester and they would begin more language-centered content courses by level 5 . We must clarify that not all students who enter our program place into level 1 their first semester, some of them may place into level 3.

By the fifth level of English the students should be near fluent and they will follow a program called Business English 1-4; these courses would present them the language they would need in varying subjects of Business. However, once the program began, we noticed differences which would change our way of thinking, planning and design.

With our current adaptations to curriculum design modeling the Common European Framework and national goals for tertiary education students entering into the Instituto's policies, it became obvious that the English the students were receiving was neither demanding nor competitive enough for the overall goals of the Business English program. We decided the students needed more language and more content-oriented material not only to become as close

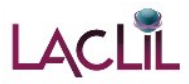

ISSN 2011-6721 (c) (i)

Bailey, A., Rey, L, \& Rosado, N. (2008). International business english program: Processes and considerations for design. Latin American Journal of Content and Language Integrated Learning, 1(1), 54-59. doi:10.5294/lacli1.2008.1.1.6 
to a $\mathrm{C} 1$ speaker as possible by the end of their forth level but to have more business content during their entire language learning experience. So, we redesigned the program.

By the beginning of this phase, we had already been teaching the Business students for two semesters with the old plan. Observations of the students during these two semesters demonstrated that the students had better base knowledge than those of the regular undergraduate program and were bored with the typical English study they were doing. So, the decision-making process was shared with the students. Simply, the teacher went into the classroom and asked the students what they wanted. The students were given the choice to continue with the program as planned, which would mean using an ESL/EFL book and adding business materials to it or we would develop a program with more authentic and practical uses for their future purposes. The students chose the latter.

Remember that the last four levels of the business program at Universidad del Norte are more business language-centered content, so our goal was not necessarily to change the current learning outcomes of levels 1-4 but rather give them more direct content for business in English throughout their language program and prepare them for their professional lives and contact with international businesses. So, we decided upon a specific set of courses to achieve this.

These courses now are:

- Levels 1 and 2: Basic Business. These courses focus on the topics presented in the book titled "Let's Talk Business" of the Tapestry series and introduce the students to general business themes with language instruction throughout.

- Level 3: Advanced Academic Preparation. This course focuses on the aspects of Academic reading and writing. The students use the information in this course to develop their overall writing skills using narrative, persuasion, cause/effect and argumentative; as well as, develop their critical reading skills by reading longer essays and stories comparative to the writing skills objectives. All of this, of course, is weaved into relevant business purposes.

- Level 4: Critical Thinking. This course is the first step for the students to learn how academic programs work in English without the stress of being in one. The content is presented in real Academic English and the students work on identifying arguments, manipulating language for persuasive purposes, and avoiding fallacious statements. This course, again, is weaved into relevant business purposes.

Now that the way had been decided, the designers and authors of this article had to design the courses as best we could, according to what our students had wanted, what they need, and what they will use. The following section will discuss our considerations for design and implementation.

\section{PHASE 2: CONSIDERATIONS FOR DESIGN}

It is necessary to reiterate the importance of the language-centered content course plans. According to Crandall and Kaufman (2002) content courses should be able to offer experiences that will motivate and encourage complex thinking for university level education (p.3). We, at Universidad del Norte, also, need to take into account our context and provide them with materials, which are relevant and encouraging for their learning purposes. So the following is a brief synopsis of how decisions were made.

For levels 1 and 2, we looked carefully through materials and decided upon the Tapestry book for its design, its implicit strategy teaching and business material throughout. Although the book is outdated and at present out of print, we felt the themes in the book are relevant for first 
time Business students. The book introduces each major theme with high vocabulary instruction and jargon, grammar instruction utilizing business tasks, readings which we are able to supplement with current information, and excellent communicative practice. This type of practice and exposure is irreplaceable for these young students.

For level 3, we took into consideration the academic preparation the students will need for real interaction with English speakers and writers throughout the world. We also believed the students needed the academic English for their language and communicative goals in their own learning processes. So, we chose material which was available, readings from the internet and other various sources to fulfill the academic writing and reading learning processes as entertaining as we could possibly design it. The program works through all the aspects of Academic English reading and writing.

For level 4, we took into consideration the needs of business majors and the critical skills they will need in future communications for presentations, sales, marketing, etc. The program works through arguments, their soundness and validity, argument by analogy, the uses and functions of language, and identifying fallacies. This level focuses on independence and the needs as professionals.

All of the above courses have been implemented and taught for a semester or more at this point in time. The classes are doing well and the students are obtaining more business language during the courses. The following section dedicates time to where we are headed in the future beginning with the newly designed course scheduled to open this coming semester (2007). The other three are still in the design phase.

\section{PHASE 3: THE WAY AHEAD}

One of the hardest parts of designing a new course is the time it takes to plan and invent. We have managed to finish and implement the teaching of the first four levels of the regular English for the Business students, and we are just beginning to focus on the more language-centered content courses, or what is titled in the student program Business English. This process is more difficult and challenging. At the beginning, we had considered teaching content-centered courses. The challenge of these courses obviously is finding content teachers and exchanging the work through departments and teachers. The second challenge was whether the Business department really wanted content in English or wanted language within the content. After a meeting for clarification, the latter was the decided facet.

So, we hired an outside consultant to help us with the design of these four courses and after meeting with her last June and this November, we have managed to design one course and begin planning the following three. The first course is called Intercultural Business Communication or BE 1; the second course, BE 2, will be called Professional Written Communication; the third course, BE 3, will be called Professional Oral Communication; and the final Business English course will be called Integrated Business English. Each course was designed to teach necessary business skills the students will need in English and Englishspeaking environments rather than specific content-based activities. Hence, the languagecentered content courses were designed to focus on the underlying content necessary in any of the aspects and fields of business that exist. So, let us begin by describing each of the courses named above in more detail.

Intercultural Business Communication is a course which will focus on intercultural communication within business environments. The course begins at the general level of culture

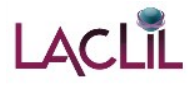

ISSN 2011-6721 (c) (i)

Bailey, A., Rey, L, \& Rosado, N. (2008). International business english program: Processes and considerations for design. Latin American Journal of Content and Language Integrated Learning, 1(1), 54-59. doi:10.5294/lacli1.2008.1.1.6 
and defines dimensions and aspects. Then the course takes a turn inwards where the students will reflect upon who they are and how they fit into the society around them. With this new found perspective the students will then learn the impact of non-verbal language and how it can differ among cultures. Once they have accomplished that, the students will begin to mix in intercultural groups by simulating business meetings from different cultural perspectives.

The considerations for the design of this course were to challenge ourselves and put together a module-based course by working together. The planning and compilation sessions went well and overall we are proud of the general design. Next semester, we will be able to decide curricula changes and adaptations.

The last three levels are in the process of being designed. During the November visit from the outside consultant we made headway as to where we were heading, but not much actual work was able to be accomplished. Business English 2 and 3 are mirror courses where BE 2 will focus on Professional Business Writing and BE 3 will focus on Professional Oral Communication. The decision was to focus these courses on the most important areas of business communication: giving bad news, persuasion and routine. Unto each of these three areas for writing there are the aspects of letter, memo and email. The oral part is just as difficult to approach depending on the recipient of the information. These courses will be case study-based where students will perform tasks responding to authentic given information and research. They should be designed within the first semester of 2007.

The final course Integrated Business English 4 is still in the thought process. We have determined that students will need general skills and knowledge to obtain a job in English if they choose to do so. So, this course focuses on the details such as resume, image, getting through the interview, professional development planning, as well as preparing them to take one of the Business English Certificates exams offered by the British Council in Bogotá, Colombia. We are not certain if the exams will happen yet; we still have some research to do in this area. However, it would be a great culmination of the hard work the students do during their English program.

\section{FINAL WORD}

Course design, course redesign, course implementation, course redesign and more course design are some of the grueling facts that make us teachers. However, this work is rewarding in the end because the living, breathing product that was created grows and flourishes as your students do. This is the reward. We have shared with you our program, our experiences and where the Instituto de Idiomas is headed in its newly created Business English Program. We now challenge you to create your content course or courses and live the experience and obviously talk about it with others. Colombia and Colombian education is growing quickly and we are the path creators. Make yours and share it. Good luck.

\section{REFERENCES}

Crandall, J. \& Kaufman, D. (2002). Content-based instruction in Higher Education Settings. Alexandria: TESOL Publications.

Stoller, F. (2002). Promoting the acquisition of knowledge in a content-based course. In Crandall, J \& Kaufman, D (eds.), Content-based instruction in Higher Education Settings. (pp. 109-123). Alexandria: TESOL Publications.

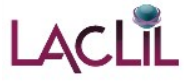

ISSN 2011-6721 (c) (i)

Bailey, A., Rey, L, \& Rosado, N. (2008). International business english program: Processes and considerations for design. Latin American Journal of Content and Language Integrated Learning, 1(1), 54-59. doi:10.5294/lacli1.2008.1.1.6 


\section{BIODATA}

Angela BAILEY holds an M.A. in TESOL from San Jose University in California. She is a teacher of English in the undergraduate language program at Universidad del Norte, Barranquilla, Colombia, level coordinator of the Business English program, and has researched reading-writing development and language use in the classroom.

Nayibe RosAdo holds a Diploma in the Teaching of English as a Foreign Language (TEFL) and an M.A. in Education from Universidad del Norte, Barranquilla, Colombia. Research areas: technology in language teaching, development of language competence, and teacher development. She is a teacher of English in the undergraduate language program and of the TEFL Diploma at Universidad del Norte.

Lourdes REY holds a Diploma in the Teaching of English as a Foreign Language ( TEFL) and an M.A. in Education from Universidad del Norte, Barranquilla, Colombia. She has co-authored research areas: technology in language teaching, development of language competence, and teacher development. She is a teacher of English in the undergraduate language program and of the TEFL Diploma at Universidad del Norte. 